\title{
Pengujian Logam Berat pada Tanah Terkontaminasi Air Limbah PLTD di Petung, Kalimantan Timur
}

\author{
Intan D W S Rini ${ }^{1}$, Adrian Gunawan ${ }^{2}$, A. Ibnu Arobi ${ }^{3}$ \\ ${ }^{1}$ Program Studi Teknik Lingkungan, Institut Teknologi Kalimantan, Balikpapan. Email: intandwi@itk.ac.id \\ ${ }^{2}$ Program Studi Teknik Kimia, Institut Teknologi Kalimantan, Balikpapan. Email: a.gunawan@itk.ac.id \\ ${ }^{3}$ PLN Sektor Balikpapan. Email: ibnurubio@gmail.com
}

\begin{abstract}
PLTD (Pembangkit Listrik Tenaga Diesel) Petung or PLTD Girimukti is located in North Penajam Paser District, East Kalimantan Province which is the capacity of $2 \times 1.0 \mathrm{MW}$. Wastewater sewerage that passed through oil palm plantations and settlements made water and soil pollution. Result of water test and soil fertility showed that there is no parameter of environmental control is higher than quality standards (PP No 101 Tahun 2014). The aim of TCLP (Toxicity Characteristic Leaching Procedure) testing is knowing the content of heavy metal in the soil. TCLP method is USEPA 3050B-96. The several heavy metals parameters are $\mathrm{Ag}, \mathrm{Hg}, \mathrm{As}, \mathrm{Zn}, \mathrm{Pb}, \mathrm{Cu}, \mathrm{B}, \mathrm{Ba}$, $C d, C r$, and $S$. The result showed that the content of these heavy metal are lower than quality standard. This indicated that the land and oil palm plantations were not polluted by heavy metals.
\end{abstract}

Keywords: Heavy Metals, TCLP, Thermal Power Plant.

\begin{abstract}
Abstrak
PLTD (Pembangkit Listrik Tenaga Diesel) Petung atau PLTD Girimukti terletak di Kabupaten Penajam Paser Utara, Provinsi Kalimantan Timur berkapasitas 2 x 1,0 MW. Saluran air limbah yang melewati area perkebunan kelapa sawit dan pemukiman diduga menyebabkan terjadinya pencemaran air dan tanah pada sekitar pembangkit tersebut. Hasil pengujian air dan kesuburan tanah menunjukkan bahwa tidak adanya parameter kualitas lingkungan yang melebihi baku mutu yaitu PP Nomor 101 Tahun 2014. Dilakukan pengujian TCLP dengan tujuan mengetahui kadar logam berat yang ada di tanah. Metode pengujian TCLP adalah USEPA 3050B-96. Uji TCLP dengan parameter beberapa logam berat, diantaranya $\mathrm{Ag}, \mathrm{Hg}, \mathrm{As}, \mathrm{Zn}, \mathrm{Pb}, \mathrm{Cu}, \mathrm{B}, \mathrm{Ba}, \mathrm{Cd}, \mathrm{Cr}$, dan $\mathrm{S}$ menunjukkan berada dibawah baku mutu yang dipersyaratkan. Hal ini menunjukkan bahwa tanah di sekitar area pemukiman dan perkebunan kelapa sawit tersebut tidak tercemar logam berat.
\end{abstract}

Kata Kunci: Pembangkit Listrik Tenaga Diesel, Logam berat, TCLP.

\section{Pendahuluan}

Sejak beroperasi pada tahun 2004, PLTD (Pembangkit Listrik Tenaga Diesel) Girimukti yang terletak daerah Petung, Desa Girimukti, Kecamatan Penajam, Kabupaten Penajam Paser Utara, Provinsi Kalimantan Timur telah membantu masyarakat sekitar untuk mendapatkan suplai listrik. Dalam pengoperasiannya, PLTD Girimukti yang berkapasitas $2 \times 1,0 \mathrm{MW}$ dilengkapi dengan beberapa unit mesin penggerak dan generator. Pengoperasian PLTD Girimukti pada awalnya berada di daerah yang jauh dari pemukiman. Akan tetapi seiring dengan perkembangan, di daerah sekitaran PLTD Girimukti mulai dikelilingi dengan pemukiman, sehingga manajemen PLTD Girimukti membuat pengolahan limbah dengan tujuan agar kegiatan PLTD Girimukti tidak mencemari lingkungan disekelilingnya. 
Beberapa pengolahan limbah yang ada di PLTD Girimukti adalah unit IPAL (Instalasi Pengolahan Air Limbah) yang berfungsi untuk mengolah air sisa kegiatan PLTD agar sesuai dengan baku mutu yang dipersyaratkan untuk dibuang ke lingkungan. Unit IPAL yang digunakan sangat sederhana, yaitu berupa unit separator atau unit pemisah yang digunakan untuk memisahkan air, solar, dan minyak pelumas sisa kegiatan. Sedangkan untuk air limbah domestiknya yang berasal dari perkantoran dan WC disalurkan ke dalam septictank dan resapan yang dibangun disekitar bangunan WC tersebut (UKL/UPL PLTD Petung, 2004).

Limbah B3 berupa pelumas dan oli yang sudah dipisahkan, beserta limbah B3 lainnya seperti kain majun dikelola dengan membangun TPS (Tempat Penampungan Sementara) limbah B3 di area PLTD Girimukti. Kemudian limbah B3 diserahkan kepada pengumpul dan pengolah limbah B3 yang sesuai dengan peraturan yang berlaku yakni Peraturan Pemerintah (PP) Nomor 101 Tahun 2014 tentang Pengelolaan Limbah B3 (Bahan Berbahaya dan Beracun).

Pada bagian sebelah timur PLTD Girimukti terdapat pemukiman warga dan perkebunan kelapa sawit kecil milik perorangan. Area ini dilalui oleh buangan saluran air limbah PLTD Girimukti menuju sungai yang ada dibelakang pemukiman ini. Pada tahun 2017 silam, ditemukan beberapa pohon kelapa sawit tumbang dan tidak dapat menghasilkan buahnya. Hasil pengujian air pada outlet IPAL PLTD Girimukti yang berada dekat dengan area perkebunan tidak menunjukkan adanya baku mutu air limbah yang melebihi baku mutu.

Perlunya ada uji kondisi tanah pada area perkebunan kelapa sawit merupakan salah satu upaya mengetahui penyebab rusaknya beberapa pohon kelapa sawit. Hasil uji kesuburan tanah yang dilakukan menunjukkan hasil yang hampir serupa bahwasanya kondisi kesuburan tanah dalam keadaan yang baik. Akan tetapi pada uji kesuburan tanah, tidak ada parameter logam berat, sehingga perlu diadakan uji kandungan logam berat dengan metode TCLP (Toxicity Characteristic Leaching Procedure). Uji TCLP dapat dilakukan dengan mengambil sampel tanah di area yang mengalami kerusakan dan area yang tidak mengalami kerusakan sebagai perbandingan.

Uji TCLP merupakan suatu pengujian yang digunakan untuk mempelajari perilaku limbah yang tersolidifikasi, dalam hal ini limbah yang telah masuk ke dalam tanah (Poon dan Lio, 1997). Uji TCLP dilakukan untuk menentukan mobilitas zat organik dan anorganik yang terdapat dalam limbah padat dan cair. Beberapa komponen zat anorganik yang diujikan antara lain Ag (Perak), As (Arsenik), B (Boron), $\mathrm{Ba}$ (Barium), Cd (Kadmium), Cr (Kromium), Cu (Tembaga), Hg (Merkuri), Pb (Timbal), dan Zn (Seng). Oleh karena itu diadakan penelitian ini dengan bertujuan untuk menguji hasil TCLP guna mengetahui kandungan logam berat pada tanah di area perkebunan kelapa sawit tersebut.

\section{Metode}

Pemilihan lokasi pengambilan sampel didasarkan pada jarak dari titik pembuangan air limbah PLTD Girimukti. Tanah yang akan diuji diambil pada dua titik yang berbeda, yaitu pada lokasi yang terkontaminasi air limbah dan pada lokasi yang tidak terkontaminasi air limbah yaitu sekitar 500 meter dari batas area terkontaminasi. Sampel tanah diambil sebanyak \pm 500 gram pada masing-masing lokasi. Berbeda dengan pengujian tanah agregat utuh yang bertujuan untuk penetapan stabilitas agregat yang membutuhkan $2 \mathrm{~kg}$ sampel untuk setiap pengujiannya. Pada setiap titik pengujian, tanah diambil pada kedalaman $30 \mathrm{~cm}$.

Tanah yang telah diambil, dimasukkan ke plastik dan diberikan label kemudian dianalisis di laboratorium. Adapun analisis pada pengujian ini bersifat single, artinya setiap tanah diuji satu kali 
analisis. Pengujian dilakukan pada hari yang sama di Laboratorium PT Geoservices Cabang Balikpapan. Adapun metode uji TCLP menggunakan metode USEPA 3050B-96.

\section{Hasil dan Pembahasan}

Hasil uji TCLP menunjukkan hasil bahwa semua kadar logam berat berada jauh di bawah ambang batas baku mutu. Berdasarkan PP Nomor 101 Tahun 2014 tentang Pengelolaan Limbah B3, baku mutu TCLP dibagi dalam dua jenis yaitu TCLP-A dan TCLP-B. Limbah B3 yang dikategorikan sebagai bahan uji TCLP-A adalah limbah B3 kategori 1, dimana merupakan limbah B3 yang berdampak akut dan langsung terhadap manusia dan dapat dipastikan akan berdampak negatif terhadap lingkungan. Limbah B3 yang dapat dikategorikan sebagai kategori 1 misalnya adalah residu dasar tangki industri kilang minyak, gas, dan panas bumi atau misalnya lampu $\mathrm{Hg}$ pada industri elektronik.

TCLP-B adalah limbah B3 kategori 2 yaitu limbah B3 yang memiliki efek tunda dan berdampak tidak langsung terhadap manusia dan lingkungan hidup serta memiliki toksisitas sub-kronis atau kronis. Tanah yang terkontaminasi dapat dikategorikan sebagai limbah B3 kategori 2 dimana efek yang dirasakan oleh penerima tidak langsung, melainkan tunda dalam jangka waktu tertentu. Lingkungan tidak mengalami perubahan dalam jangka waktu yang singkat melainkan setelah beberapa tahun.

Gambar 1 menunjukkan proses sampling yang dilakukan pada titik pertama yaitu tanah yang diduga terkontaminasi. Pada area tanah terkontaminasi terdapat beberapa pohon kelapa sawit. Sedangkan tanah yang tidak terkontaminasi terletak beberapa ratus meter dan juga ditumbuhi pohon kelapa sawit.

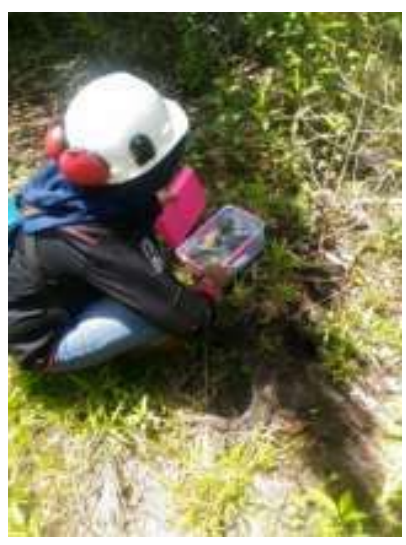

Gambar 1. Proses Sampling di Area Perkebunan Kelapa Sawit

Tabel 1. Baku Mutu TCLP Zat Anorganik

\begin{tabular}{|cc|c|c|}
\hline \multicolumn{2}{|c|}{ Parameter } & $\begin{array}{c}\text { Baku } \\
\text { Mutu } \\
\text { TCLP-A } \\
\text { (ppm) }\end{array}$ & $\begin{array}{c}\text { Baku } \\
\text { Mutu } \\
\text { TCLP-B } \\
\text { (ppm) }\end{array}$ \\
\hline Perak & $\mathrm{Ag}$ & 40 & 5 \\
\hline Arsen & $\mathrm{As}$ & 3 & 0,5 \\
\hline Boron & $\mathrm{B}$ & 150 & 25 \\
\hline Barium & $\mathrm{Ba}$ & 210 & 35 \\
\hline Kadmium & $\mathrm{Cd}$ & 0,9 & 0,15 \\
\hline Kromium & $\mathrm{Cr}$ & 15 & 2,5 \\
\hline Tembaga & $\mathrm{Cu}$ & 60 & 10 \\
\hline
\end{tabular}




\begin{tabular}{|cc|c|c|}
\hline \multicolumn{2}{|c|}{ Parameter } & $\begin{array}{c}\text { Baku } \\
\text { Mutu } \\
\text { TCLP-A } \\
\text { (ppm) }\end{array}$ & $\begin{array}{c}\text { Baku } \\
\text { Mutu } \\
\text { TCLP-B } \\
\text { (ppm) }\end{array}$ \\
\hline Merkuri & $\mathrm{Hg}$ & 0,3 & 0.05 \\
\hline Timbal & $\mathrm{Pb}$ & 3 & 0.5 \\
\hline Selenium & $\mathrm{Se}$ & 3 & 0.5 \\
\hline Seng & $\mathrm{Zn}$ & 300 & 50 \\
\hline
\end{tabular}

Berikut adalah hasil uji TCLP pada bahan sampel yaitu tanah yang terkontaminasi dan tanah yang tidak terkontaminasi. Hasil menunjukkan bahwa kedua hasilnya mengandung logam berat dengan kadar yang sangat rendah dan masih di bawah baku mutu. Dengan adanya hasil ini diketahui bahwa tanah pada area di sekitar buangan air limbah tidak berpotensi mencemari tanah.

Tabel 2. Hasil Uji TCLP

\begin{tabular}{|c|c|c|c|c|}
\hline \multirow{2}{*}{\multicolumn{2}{|c|}{ Parameter }} & \multicolumn{2}{|c|}{ Hasil Uji } & \multirow{2}{*}{$\begin{array}{c}\text { Baku } \\
\text { Mutu } \\
\text { TCLP-B } \\
\text { (ppm) }\end{array}$} \\
\hline & & Tanah Tidak & Tanah & \\
\hline Perak & $\Delta \alpha$ & $<005$ & $\angle 005$ & 5 \\
\hline Arsen & As & $<0.0009$ & $<0.0009$ & 0.5 \\
\hline Boron & $\mathrm{B}$ & 0.478 & 0.411 & 25 \\
\hline Barium & $\mathrm{Ba}$ & 0.064 & 0.094 & 35 \\
\hline Kadmium & $\mathrm{Cd}$ & $<0.003$ & $<0.003$ & 0.15 \\
\hline Kromium & $\mathrm{Cr}$ & $<0.008$ & $<0.008$ & 2.5 \\
\hline Tembaga & $\mathrm{Cu}$ & $<0.009$ & $<0.009$ & 10 \\
\hline Merkuri & $\mathrm{Hg}$ & $<0.0009$ & $<0.0009$ & 0.05 \\
\hline Timbal & $\mathrm{Pb}$ & $<0.08$ & $<0.08$ & 0.5 \\
\hline Selenium & $\mathrm{Se}$ & $<0.001$ & $<0.001$ & 0.5 \\
\hline Seng & $\mathrm{Zn}$ & $<0.02$ & $<0.02$ & 50 \\
\hline
\end{tabular}

\section{Logam Arsen}

Logam arsen merupakan salah satu logam berbahaya yang akut sehingga dapat menyebabkan keracunan. Keracunan arsen dapat berasal dari makanan yang mengandung lebih dari $100 \mathrm{mg}$ unsur tersebut. Akan tetapi logam arsen juga dapat menyebabkan keracunan kronis, apabila terkandung pada makanan dengan jumlah yang sedikit tetapi dalam waktu yang cukup lama. Hal ini menunjukkan bahwa logam arsen bersifat karsinogenik. Arsen merupakan logam berat yang berasal dari pembakaran bahan bakar fosil terutama batubara (Achmad, 2004).

Pada penelitian ini, kandungan logam arsen tidak dapat teridentifikasi secara jelas, sehingga diketahui bahwa pembacaan menunjukkan berada dibawah konsentrasi 0,05 ppm. Baku mutu TCLP-B menunjukkan angka maksimum adalah $5 \mathrm{ppm}$. Dengan demikan diketahui bahwa kandungan logam arsen pada tanah terkontaminasi berada dibawa baku mutu kualitas lingkungan. 


\section{Logam Kadmium}

Akumulasi kadmium (Cd) pada tanaman dapat menghambat penyerapan unsur hara (Pardo dkk, 2013), menghambat distribusi fotosintat (Xue dkk, 2013), menghambat laju fotosintesis, aktivitas enzim (Arbon dkk, 2011), meningkatkan senyawa peroksida (Liu dan Templeton 2007), dan menyebabkan perubahan genetik (Dezar, Fedrigo, dan Chan 2005). Konsumsi hasil tanaman pangan tercemar logam berat termasuk cadmium, dapat menyebabkan akumulasi logam berat dalam organ tubuh yang menjadi penyebab berbagai macam penyakit maupun gangguan fungsi organ tubuh seperti patah tulang, kanker, kerusakan jantung, hati, ginjal, paru-paru, dan mutagenesis yang dapat menyebabkan kematian (Portier, 2012).

Kadmium pertama kali ditemukan pada bebatuan calamine oleh ilmuwan jerman Friedric Strohmeyer pada tahun 1817. Kadmium terdapat di seluruh lapisan permukaan bumi dalam konsentrasi rendah yaitu 0,1-0,5 ppm (Smiciklas, 2003). Pengaruh pencemaran kadmium pada tanaman sulit terdeteksi apabila hanya diukur dari laju pertumbuhan tanaman dan hasil tanaman. Tanaman yang tumbuh pada lahan terkontaminasi umumnya masih dapat tumbuh normal, tetapi laju fisiologi tanamannya telah berubah (Sutrisno dan Henny Kuntyaastuti, 2013).

Hasil penelitian menunjukkan logam kadmium baik pada lahan terkontaminasi maupun pada lahan tidak terkontaminasi air limbah PLTD Girimukti, lebih kecil daripada 0,003 ppm. Baku mutu PP Nomor 101 Tahun 2014 Lampiran III adalah 0,15 ppm. Hal ini menyatakan bahwa lahan terkontaminasi tidak mengandung kadar logam kadmium melewati batas baku mutu sehingga lahan tidak mengalami pencemaran tanah.

\section{Logam Timbal}

Timbal merupakan bahan kimia yang termasuk dalam kelompok logam berat, Timbal $(\mathrm{Pb})$ adalah salah satu bahan pencemar utama saat ini di lingkungan. Hal ini bisa terjadi karena sumber utama pencemaran timbal adalah dari emisi gas buang kendaraan bermotor. Selain itu timbal juga terdapat dalam limbah cair industri yang pada proses produksinya menggunakan timbal, seperti industri pembuatan baterai, industri cat, dan industri keramik. Timbal digunakan sebagai adiktif pada bahan bakar, khususnya bensin di mana bahan ini dapat memperbaiki mutu bakar. Bahan ini sebagai anti knocking (anti letup), pencegah korosi, anti oksidan, diaktifator logam, anti pengembunan dan zat pewarna. Adanya timbal pada komponen lingkungan yaitu air, tanah, dan udara memungkinkan berkembangnya transmisi pencemaran menjadi lebih luas kepada berbagai mahkluk hidup, termasuk manusia sehingga menimbulkan gangguan kesehatan, seperti terganggunya sistem saluran pernapasan, sintesa darah merah, anemia, dan penurunan intelegensia pada anak (Naria,2005).

Logam timbal $(\mathrm{Pb})$ yang mencemari tanah dapat berasal dari kegiatan industri pembuatan lempengan baterai, aki, bahan peledak, pateri, pembungkus kabel, pigmen, cat anti karat, pelapisan logam, serta penggunaan pupuk fosfat dalam bidang pertanian. Selain itu penggunaan bahan bakar yang mengandung timbal menyebabkan udara tercemar oleh timbal, sehingga secara tidak langsung dapat mencemari tanah, baik melalui proses sedimentasi maupun presipitasi. Adanya polutan berupa logam $\mathrm{Pb}$ dalam jumlah yang berlebihan dapat menyebabkan lingkungan tidak dapat mengadakan pembersihan sendiri (self purification) (Novandi dkk, 2014).

Berdasarkan Tabel 1, diketahui bahwa kadar logam timbal pada kedua lahan tersebut adalah kurang dari 0,08 ppm. Menurut PP Nomor 101 Tahun 2014, pada bahan uji kategori TCLP-B memiliki batas baku mutu maksimal sebesar 0,5 ppm. Dengan demikian dapat disebutkan bahwa kadar logam timbal pada 
lahan terkontaminasi dan lahan tidak terkontaminasi berada dibawah ambang batas sehingga dapat disimpulkan tidak ada pencemaran logam timbal pada kedua lahan tersebut.

\section{Logam Merkuri}

Merkuri merupakan logam yang sangat toksik terhadap organisme, dalam penggunaan atau aktivitas tertentu merkuri akan disebarkan ke lingkungan baik berupa bahan pertanian, obat-obatan, cat, kertas, pertambangan serta sisa buangan industri (Pryde dalam Alfian, 2006). Semua bentuk merkuri, baik dalam bentuk unsur, gas maupun dalam bentuk garam organik adalah beracun, jika masuk ke dalam tubuh manusia secara terus- menerus akan menyebabkan kerusakan permanen pada otak, hati dan ginjal.(Roger dkk, dalam Alfian, 2006), kerusakan rambut dan gigi, hilangdaya ingat dan terganggunya sistem syaraf (Setiabudi, 2005). Penyakit Minamata akibat mengkonsumsi pangan tercemar merkuri yang berasal dari buangan sisa industri menelan korban cukup banyak (Alfian, 2006).

Pada Tabel 1 telah tercantum bahwa kadar merkuri pada kedua sampel uji adalah kurang dari 0,0009 ppm. Nilai uji ini sangat rendah apabila dibandingkan dengan standar baku mutu kadar logam merkuri uji TCLP-B PP Nomor 101 Tahun 2014 yaitu 0,05 ppm. Kesimpulannya adalah lahan terkontaminasi air limbah PLTD Girimukti tidak mengandung kadar logam merkuri melebihi baku mutu.

\section{Kesimpulan}

Kesimpulan yang dapat diambil dari hasil diatas adalah tidak adanya kandungan logam berat yang terdapat pada tanah yang berada di area perkebunan kelapa sawit. Kerusakan yang terjadi pada beberapa pohon kelapa sawit tidak diakibatkan adanya pencemaran tanah dan air dari saluran pembuangan air limbah PLTD Girimukti.

\section{Daftar Pustaka}

Achmad, Rukaesih. 2004. Kimia Lingkungan. Jakarta : Penerbit Andi.

Alfian, Z. 2006. Merkuri: Antara Manfaat dan Efek Penggunaannya Bagi Kesehatan Manusia dan Lingkungan.

Arbon, K.S., C.M. Christensen, W.A. Harvey, and S.J. Heggland. 2011. Cadmium exposure activates the ERK signaling pathway leading to alteredosteoblast gene expression and apoptotic death in Saos-2 cells. Food and Chem. Toxicology. 50:198-205.

Dezar, C.A., G.V. Fedrigo, and R.L. Chan. 2005. The promoter of the sunflower HD-Zip protein gene Hahb4 directs tissue-specific expression and is inducible by water stress, high salt concentrations and ABA. Plant Science J.169(2): 447-456.

Liu, Y. and D. M. Templeton. 2007. Cadmium activates CaMK-II and initiates CaMK-II-dependent apoptosis in mesangial cells. FEBS Letters. 581:1481-1486.

Naria, E. 2005. Mewaspadai Dampak Bahan Pencamar Timbal $(\mathrm{Pb})$ di Lingkungan Terhadap Kesehatan. Jurnal Komunikasi Penelitian Vol.17, No.4 2005.

Novandi R, Rita Hayati, dan Titin Anita Zahara. 2014. Remediasi Tanah Tercemar Logam Timbal (Pb) Menggunakan Tanaman Bayam Cabut (Amaranthus tricolor L.)

Pardo, B.S. R.O. Carpena, R. Carpena, and P. Zornoza. 2013. Kadmium in white lupin nodules: Impact on nitrogen and carbon metabolism. J. of Plant Physiol. 170:265-271.

Portier, C.J. 2012. Toxicological profile for cadmium. Public Health Service Agency for Toxic Substances and Disease Registry. Georgia. 487 pp.

Poon, C. S. and Lio, K. W., 1997, The Limitation of the Toxicity Characteristic Leaching Procedure for Evaluating Cement-based Stabilised/Solidified Waste Forms.

Setiabudi, B. T., 2005. Penyebaran Merkuri Akibat Usaha Pertambangan Emas Di Daerah Sangon,Kabupaten Kulon Progo, D.I. Yogyakarta

Smiciklas, I.D. 2003. Cadmium immobilization by hydroxyapatite. Chem Industry 57(3):101-106. 
Sutrisno dan Henny Kuntyaastuti. 2015. Pengelolaan Cemaran Kadmium Pada Lahan Pertanian Di Indonesia. Diterbitkan di Buletin Palawija Vol. 13 No. 1:83-91.

UKL dan UPL PLTD Petung, 2004, PT PLN (Persero) Proyek Induk Pembangkit dan Jaringan Kalimantan.

Xue, Z.C., H.Y. Gao, and L.T. Zhang. 2013. Effects of cadmium on growth, photosynthetic rate and chlorophyll content in leaves of soybean seedlings. Biologia Plantarum 57(3):587-590. 